
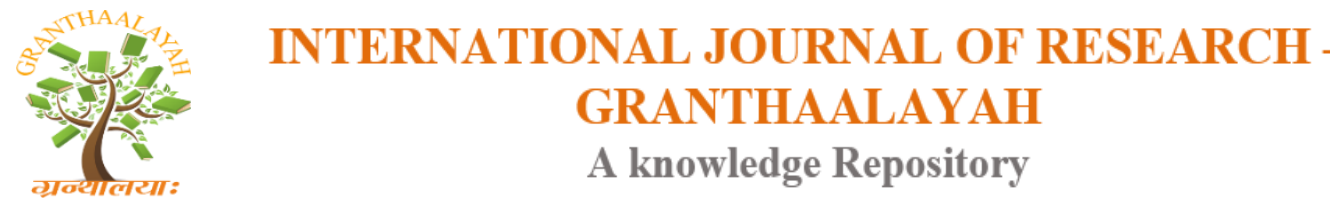

Science

\title{
PHYSICO-CHEMICAL AND PHYTOCHEMICAL SCREENING OF n- HEXANE EXTRACT OF LEPTADENIA HASTATA LEAVES: A PROPOSED HERBAL REMEDY IN THE TREATMENT OF DIABETES MELLITUS
}

\author{
Attah M.O.O ${ }^{1}$, Jacks T.W ${ }^{2}$, Garba S.H. ${ }^{1}$, Mshelia H.E. ${ }^{3}$ \\ ${ }^{1}$ Department of Human Anatomy, College of Medical Sciences, University of Maiduguri, \\ P.M.B. 1069, Maiduguri, Borno State, Nigeria \\ 2 Department of Human Anatomy, Rivers State University, Port-Harcourt, Rivers State, Nigeria \\ ${ }^{3}$ Department of Pharmacognosy and Ethnopharmacy, Faculty of Pharmaceutical Sciences, \\ Usman Dan-fodio University, Sokoto, Sokoto State, Nigeria
}

\begin{abstract}
Background: Leptadenia hastata is a leafy, climbing plant of whose root, leaf and bark is widely consumed in Northern Nigeria. Decoctions made from the leaf is locally used in treatment of diabetes as well as for numerous trado-medicinal processes. This study investigates the physicochemical as well as phytochemical compounds present in the n-hexane extract of Leptadenia hastata.

Method: Physical and chemical profile was determined using Smart Spectro test kits and a mass spectrometer to determine the presence of elements and physical properties.

Results: Phytochemical analysis revealed the presence of steroids, triterpenoids and cardiac glycosides. The elemental analysis revealed that Na, SO4 and PO4 had the highest levels in the extract. $\mathrm{Pb}, \mathrm{Hg}$ and $\mathrm{Cd}$ were not detected which showed that the plant extract was not toxic. Other elements (NO4, Mn, Fe, K, Ni, Si, Cn, $\mathrm{Zn}, \mathrm{Ca}, \mathrm{Mg}, \mathrm{NH} 4, \mathrm{Cr}$ and $\mathrm{F}$ ) were present in varying concentrations which may contribute to its nutritive composition.

Conclusions: Various elements present in Leptadenia hastata may have either a direct or indirect role in the control and management of diabetes mellitus, since diabetes is associated with marked alterations in trace elements concentrations and may replace diminished element stores in the treatment of diabetes mellitus.
\end{abstract}

Keywords: Leptadenia Hastata; Physico-Chemical; Phytochemical; Analysis; Elements; NHexane.

Cite This Article: Attah M.O.O, Jacks T.W, Garba S.H., and Mshelia H.E. (2019). "PHYSICOCHEMICAL AND PHYTOCHEMICAL SCREENING OF n-HEXANE EXTRACT OF LEPTADENIA HASTATA LEAVES: A PROPOSED HERBAL REMEDY IN THE TREATMENT OF DIABETES MELLITUS." International Journal of Research Granthaalayah, 7(2), 45-57. https://doi.org/10.29121/granthaalayah.v7.i2.2019.992. 


\section{Introduction}

Medicinal plants and herbs have always played an important role in traditional medicine as well as treatment of ailments and are widely consumed as home remedies especially in developing and third world countries. In the past twenty years, the popularity and consumption of medicinal herbs and of their preparations have increased worldwide, thus, scientific confirmation about the quality, efficacy and safety of these plants is required $(1,2)$. Herbal preparations from medicinal plants are preferred mostly in third world countries because of the cost effectiveness as well as its availability in many of the rural localities. Many of these herbs are passed down from one generation to the next and are ingested for varying range of ailments. Many of the medicinal properties in these plants depend on their phytochemical constituents which consists of minerals and other nutrients. Fresh plant material contains $80-90 \%$ water and of the remainder, over $90 \%$ consists of $\mathrm{C}, \mathrm{H}$ and 0 [1]. Angiosperms contain normally the elements such as $\mathrm{C}, \mathrm{H}, \mathrm{O}, \mathrm{N}, \mathrm{P}, \mathrm{S}, \mathrm{K}, \mathrm{Ca}, \mathrm{Mg}, \mathrm{Fe}, \mathrm{B}, \mathrm{Mn}$, $\mathrm{Cu}, \mathrm{Zn}, \mathrm{Mo}, \mathrm{Cl}, \mathrm{Na}$, Si, and V. The trace metals such as $\mathrm{Zn}, \mathrm{Cd}, \mathrm{Cu}, \mathrm{Mn}, \mathrm{Al}, \mathrm{Fe}, \mathrm{As}, \mathrm{V}, \mathrm{Pb}$ and $\mathrm{Se}$ are also found in herbs [2,3]. It has been found that different metals are very important for the proper functioning of human body. The deficiency of these metal ions causes many ailments. Trace elements have important roles in combating a variety of human aliments and diseases [3-6] which was observed by the study of the elemental content of many indigenous medicinal plants. These micronutrients are essential and required daily by the body in trace amounts to function properly [5,6]. Micronutrients can be classified as the macro elements and trace elements [5]. The macro elements include phosphorous, chloride, calcium, sodium, magnesium, iron and potassium. The trace elements include boron, cobalt, copper, sulfur, chromium, fluoride, iodine, selenium, zinc, manganese and molybdenum [5]. In our body macro elements have multiple functions. They initiate hormone secretion with the help of vitamins and help in speeding up the various metabolic processes. Trace elements participate in tissue, cellular and subcellular functions. Trace elements interact with macro elements and vitamins to enhance their effects on the body. Several research studies have revealed that there is a direct association of macro and trace elements with diabetes mellitus [6]. Diabetes mellitus has been found to be associated with abnormalities in the metabolism of some of the elements such as $\mathrm{Cu}, \mathrm{Zn}, \mathrm{Fe}, \mathrm{Se}, \mathrm{Mg}, \mathrm{Cr}, \mathrm{V}, \mathrm{Ca}$ and $\mathrm{K}$ [7,8]. Leptadenia hastata (Pers) Decne (Family-Asclepiadaceae), commonly known as yadiya is an edible nondomesticated vegetable collected in wild throughout Africa. It is a voluble herb with creeping latex stems, glabescent leaves, glomerulus and racemus flowers as well as follicle fruits. Wild plants like Leptadenia hastata provides food security during seasonal changes and are used medicinally in many areas [9]. Ethno-botanical information obtained from traditional medical practitioners in northern Nigeria revealed that it has been used locally for the treatment of diabetes mellitus. The antimicrobial effect have been also reported by [9, 10], [11-13] evaluated the hypo-glycemic and hypo-lipidemic effects of water and methanol and root extracts of L. hastata in normal and alloxaninduced diabetic rat models and found out that the plant has glucose lowering properties. The various elements present in this medicinal plant may have either a direct or indirect role in the control and management of diabetes mellitus, since diabetes is associated with marked alterations in the concentrations of trace elements. The deficiency of mineral elements which are present in the diabetic condition can also be overcome by supplementation through consuming Leptadenia hastata. The important applications of some plants have long been published but a large number of them remain unexplored as yet. This study investigates the physico-chemical as well as phytochemical compounds present in the n-hexane extract of Leptadenia hastata, using solvent extraction method with n-hexane as the extracting solvent. 


\section{Materials and Methods}

\section{Collection, Identification and Storage of Plant Material}

Leptadenia hastata was collected from a garden in the University of Maiduguri, Borno State, authenticated by a plant taxonomist, from the Department of Biological Sciences, Faculty of Science, University of Maiduguri. The leaves were harvested, washed and shade dried for a period of two weeks and then ground to powder using a mortar and pestle. The powder was sieved to obtain the fine powder, it was then labeled and stored for use.

\section{Extraction of Plant Material}

Maceration technique as described by [14] was used for extraction in the current study. The leaf powder weighing $500 \mathrm{~g}$ was dissolved in 3 liters of $\mathrm{n}$-hexane in a 5 liter stoppered container. Maceration involved soaking the plant which is allowed to stand at room temperature for a period of 3 days at the minimum with periodic agitation. The process softened and broke the plant's cell wall to release the soluble phytochemicals. After 3 days, the mixture was filtered using Whatman's filter paper. The resulting n-hexane filtrate was concentrated to dryness in-vacuo using an evaporator and the resulting powder was kept in an air-tight container and refrigerated.

\section{Phytochemical Screening}

Different chemical tests were carried out on the hexane fraction to identify the presence of various chemical constituents like cardiac glycosides, triterpenoids and steroids in the hexane fraction. These tests were carried out in the Pharmacognosy Laboratory, Department of Pharmacognosy, Faculty of Pharmacy, University of Maiduguri.

\section{Test for Steroids}

Liebermann-Buchard Test: A small portion of the extract was dissolved in $2 \mathrm{mls}$ chloroform. Sulphuric acid was carefully added to form a lower layer. A reddish brown colour at the interface indicated the presence of a steroidal ring [15]

Salkowski Test: A small quantity of the extract was dissolved in $1 \mathrm{ml}$ chloroform and to it $1 \mathrm{ml}$ of concentrated $\mathrm{H}_{2} \mathrm{SO}_{4}$ was added down the test tube. Formation of red or yellow coloration indicated the presence of steroidal ring nucleus [16].

\section{Test for Triterpenoids}

An amount of $0.8 \mathrm{~g}$ of selected plant sample was taken in a test tube, then $10 \mathrm{ml}$ of methanol poured in it, shaken well and filtered to take $5 \mathrm{ml}$ extract of plant sample. Then $2 \mathrm{ml}$ of chloroform was mixed in extract of Leptadenia hastata and $3 \mathrm{ml}$ of sulphuric acid was also added. Formation of reddish brown color indicated the presence of triterpenoids [16].

\section{Test for Terpenes}

A little portion of the extract was dissolved in ethanol. To which $1 \mathrm{ml}$ of acetic acid was added followed by the addition of conc. $\mathrm{H}_{2} \mathrm{SO}_{4}$. Change of colour from pink to violet indicated the presence of terpenes [16]. 


\section{Test for Cardiac Glycosides}

Salkoski test was used to identify cardiac glycosides. $0.5 \mathrm{~g}$ of the extract was dissolved in $2 \mathrm{ml}$ of chloroform and sulphuric acid carefully added to form a lower layer. Formation of reddish-brown colour at the interface indicated the presence of a steroidal ring i.e. a glycone portion of the cardiac glycoside [16].

\section{Elemental Screening of the Extract}

The elemental constituents of n-hexane extract of Leptadenia hastata were determined by analyzing the extract in the Marine Lab of National Agency for Food and Drug Administration and Control (NAFDAC), Maiduguri office. Smart Spectro test kits (Hampshire, UK) were used for the analysis and a mass spectrometer 2000 was used to determine the elemental content in the hexane extract of Leptadenia hastata.

\section{Determination of Phosphate level}

The reactor was preheated to $150 \pm 2^{0} \mathrm{C}$, the cap was removed from a total phosphorus acid reagent tube, and $1.0 \mathrm{ml}$ pipette was used to add $5.0 \mathrm{ml}$ of sample water. Then $0.15 \mathrm{~g}$ used to add one level measure of digestion reagent powder was added to each test tube and the bottle capped tightly and shaken till the powder completely dissolved. Test tubes placed in the reactor for 30 minutes. At the end of the heating period, the reactor was turned off and tubes were removed from the reactor block and allowed to cool at room temperature. The caps were carefully removed from the digested tubes and $2 \mathrm{ml}$ of total phosphorus HR hydroxide reagent was added to each tube and the tubes inverted and mixed. Then, total phosphorus hydroxide reagent was added to each tube, then waited for seven minutes. The blank tube was inserted and scanned before being removed. The sample test tube was inserted into the spectrometer and scanned. The result was recorded as Total Phosphorus in mg/l PO4.

\section{Determination of Lead}

To a test tube, $5 \mathrm{ml}$ of sample. $5 \mathrm{ml}$ of ammonium chloride buffer and 3 drops of sodium cyanide were added. Then, $0.5 \mathrm{~m}$ of sodium indicator and $0.5 \mathrm{ml}$ of stabilizing reagent were added and the solution was mixed. The first reading was taken using a spectrometer and then 3 drops of reagent was added before a second reading was taken. The total lead content was determined by subtracting the second reading from the first.

\section{Determination of Sulphates}

A test tube was filled with sample water to the $10 \mathrm{ml}$ line with the sample. The tube was inserted into the chamber of the spectrometer and screened as blank. Then, sulfate reagent was added, capped and shaken until the powder dissolved. Development of a white precipitate indicated the presence of sulfates.

\section{Determination of Nitrates}

A test tube was filled with sample water to the $10 \mathrm{ml}$ line with the sample. The tube was inserted into the chamber of the spectrometer and screened as blank. Crushed nitrate spectrophotometric grade tablet was added and the test tube inverted 60 times per minute for 2 minutes the test tube was waited for 5 minutes and then scanned. 


\section{Determination of Manganese}

A test tube was filled with sample water to the $10 \mathrm{ml}$ line with the sample. The tube was inserted into the chamber of the spectrometer and screened as blank. The tube was removed from the spectrometer and $2 \mathrm{ml}$ of hardness buffer reagent was added to it. The mixture was swirled and two drops of sodium cyanide added along with $0.5 \mathrm{ml}$ of manganese indicator reagent. This was then inserted tube into the chamber and scanned to obtain the results.

\section{Determination of Iron}

A test tube was filled with sample water to the $3 \mathrm{ml}$ line with the sample. The tube was inserted into the chamber of the spectrometer and screened as blank. The tube was removed from the spectrometer and $2 \mathrm{ml}$ of hardness buffer reagent was added to it. $3 \mathrm{ml}$ of sample was added to an iron vial. This was shaken vigorously for 15 seconds and waited for 2 minutes. The tube was inserted into the chamber and scanned.

\section{Determination of Potassium}

A test tube was filled with sample water to the $10 \mathrm{ml}$ line with the sample. The tube was inserted into the chamber of the spectrometer and screened as blank. The tube was removed from the spectrometer and 4 drops of sodium hydroxide was added to it and then mixed. One measure of tetraphenylboric powder was added and the test tube was shaken vigorously until all the powder was dissolved. At the end of a 5 minute waiting period, the test tube was again mixed to suspend any set precipitate, then immediately inserted into the chamber and scanned.

\section{Determination of Nickel}

$10 \mathrm{ml}$ of sample water was poured into a glass test tube and $1 \mathrm{ml}$ of hydrochloric acid was added to it. Two measures of ammonium persulfate reagent and two drops of silver nitrate solution were also added and mixed. $5 \mathrm{ml}$ of sodium citrate and $1 \mathrm{ml}$ of ammonium hydroxide concentrate was then mixed and diluted to $25 \mathrm{ml}$ with deionized water. $1 \mathrm{ml}$ of dimethylglyoxime was again added and mixed and waited for 20 minutes for color development. A clean test tube was filled to the $10 \mathrm{ml}$ line with the developed test sample and a second clean test tube filled to the $10 \mathrm{ml}$ line with deionized water or untreated test sample. This was scanned as the blank. The test sample was inserted into the chamber and scanned.

\section{Determination of Cadmium}

A test tube was filled with sample water to the $10 \mathrm{ml}$ line with the sample. The tube was inserted into the chamber of the spectrometer and screened as blank. The tube was removed from the spectrometer and $1 \mathrm{ml}$ of buffered ammonia reagent and sodium citrate was added to it and then mixed and $0.5 \mathrm{ml}$ indicator added. This mixture was immediately insert into the chamber and then scanned.

\section{Determination of Silica}

A test tube was filled with sample water to the $10 \mathrm{ml}$ line with the sample. The tube was inserted into the chamber of the spectrometer and screened as blank. The tube was removed from the spectrometer and 6 drops of Silica Reagent \# 1, 12 drops of Silica Reagent \# 2, 8 drops of Silica Reagent \# 3 and one measure of Silica Reagent \# 4 was added and mixed gently until the powder dissolved and there was color development. This mixture was immediately insert into the chamber and then scanned. 


\section{Determination of Cyanide}

A test tube was filled to the $10 \mathrm{ml}$ line with the sample solution. This was tested with a $\mathrm{pH}$ paper and $\mathrm{pH}$ immediately detected using a color chart. The $\mathrm{pH}$ was raised the $\mathrm{pH}$ by adding sodium hydroxide, one drop at a time while stirring. The $\mathrm{pH}$ was adjusted until $\mathrm{pH}$ was between 10.5 and 11.5. The tube was inserted in the chamber and scanned as blank. $1 \mathrm{ml}$ of cyanide buffer and cyanide indicator reagent were added. The solution was mixed and the tube inserted into the chamber and scanned.

\section{Determination of Ammonia}

A test tube was filled with sample water to the $10 \mathrm{ml}$ line with the sample. The tube was inserted into the chamber of the spectrometer and screened as blank. The tube was removed from the spectrometer and 2ml of Salicylate Ammonia \# 1 and two measures of Salicylate Ammonia \# 2, Salicylate Ammonia \# 3 reagent powder were added. The tube was shaken and waited for maximum color development. The solution was then mixed and inserted into the chamber and scanned.

\section{Determination of Zinc}

A test tube was filled with sample water to the $10 \mathrm{ml}$ line with the sample. The tube was inserted into the chamber of the spectrometer and screened as blank. The tube was removed from the spectrometer and one measure of sodium ascorbate powder and one measure of zinc buffer powder was added. This was shaken vigorously for 1 minute and three drops of sodium cyanide, $1 \mathrm{ml}$ of dilute zinc indicator solution and 4 drops of formaldehyde solution added. The test tube was inserted into the reactor and scanned.

\section{Determination of Magnesium and Calcium}

$3 \mathrm{ml}$ to the sample was added to the vial and inserted into the chamber and scan as blank. $3 \mathrm{ml}$ of sample to a calcium hardness was added to the vial and it was shaken vigorously, inserted into the chamber and scanned for the result.

\section{Determination of Sodium}

The sodium test involved three separate titrations that determined the anions and cations in aqueous solution. These results were then used in the formula:

ppm Sodium $=(\mathrm{A}+\mathrm{B}-\mathrm{C}) \times 0.46$

$\mathrm{A}=\mathrm{HCO} 3$ determined by $\mathrm{pH}$ titration

$\mathrm{B}=\mathrm{SO} 4$ and $\mathrm{Cl}$ determined by $\mathrm{pH}$ titration after ion exchange

$\mathrm{C}=\mathrm{Ca} 2+$ and $\mathrm{Mg} 2+$ determined by total hardness titration

\section{Procedure A}

$10 \mathrm{ml}$ of the sample were added to the test tube. In addition to that, 3 drops of total alkalinity indicator and sulfuric acid is inserted with a titrator tip at the center hole of the test tube cap. The plunger was used to titrate until the blue-green color changed to red-orange. The result was read directly from the titrator in ppm $\mathrm{CaCo} 3$ ( $\mathrm{HCO} 3$ and $\mathrm{CO} 3)$ and recorded as $\mathrm{A}$.

\section{Procedure B}

The test tube was filled with $4 \mathrm{ml}$ of deionized water in $1.0 \mathrm{ml}$ increments until the discharge was clear. The second test tube was filled to the $5.0 \mathrm{ml}$ line and a third test tube was filled exactly to 
the $10 \mathrm{ml}$ line with the treated sample. 3 drops of total alkalinity indicator was added to it and the second direct reading titration was done with sodium hydroxide. This was titrated till the colour changed from red or red-orange to blue or blue-green. The results were read from the titrator in ppm $\mathrm{CaCO} 3$ ( $\mathrm{SO} 4$ and $\mathrm{Cl}$ ) and recorded as result $\mathrm{B}$.

\section{Procedure C}

A test tube was filled with $12.9 \mathrm{ml}$ line with the sample, 5 drops of Hardness Reagent \#5, one Hardness tablet Reagent \#6 and Hardness Reagent \#7 and the tube was gently swirled the tube, and titrated till the colour changed from red to clear blue. The results from the titrator in ppm $\mathrm{CaCo} 3(\mathrm{Ca} 2+$ and $\mathrm{Mg} 2+)$ were read and recorded the as $\mathrm{C}$.

The sodium content of the test sample was calculated from the following formula:

(Result A + Result B - Result C) X $0.46=$ Sodium

\section{Determination of Mercury}

A test tube was filled with sample water to the $10 \mathrm{ml}$ line with the sample. The tube was inserted into the chamber of the spectrometer and screened as blank. The tube was removed from the spectrometer and $3 \mathrm{ml}$ of acetate buffer and $0.5 \mathrm{ml}$ of prepared indicator was added. The test tube was capped and mixed and then inserted into the chamber and scanned. The results were recorded as mercury.

\section{Determination of Chromium}

A test tube was filled with sample water to the $10 \mathrm{ml}$ line with the sample. The tube was inserted into the chamber of the spectrometer and screened as blank. The tube was removed from the spectrometer and one measure of chromium reagent powder till the powder dissolved. It was waited about 3 minutes for full colour development. During the waiting period, a piece of filter paper was folded to form a cone which was pushed into a funnel. At the end of 3 minute waiting period, the sample was filtered into a clean tube and inserted into a chamber and scanned.

\section{Determination of Manganese}

A test tube was filled with sample water to the $10 \mathrm{ml}$ line with the sample. The tube was inserted into the chamber of the spectrometer and screened as blank. The tube was removed from the spectrometer and 2 measures of hardness buffer reagent was added and the mixture was swirled and to the mixture, two drops of sodium cyanide and $0.5 \mathrm{ml}$ of manganese indicator reagent was added. This was capped and mixed and the test tube was inserted into the chamber and scanned.

\section{Determination of Fluoride}

This test required a reagent blank. The test tube was filled with clear, colourless, fluoride-free water to the $10 \mathrm{ml}$ line and $0.5 \mathrm{ml}$ of sodium arsenite solution as well as 2 measures of acid zirconyl reagent were added. This was capped and mixed thoroughly. This mixture was scanned as the blank reagent. Another test tube was filled with sample water and $0.5 \mathrm{ml}$ of sodium arsenite solution and two measures of acid zirconyl reagent was added. This test tube was inserted into the chamber and scanned. 


\section{Physical Screening of the Extract}

Smart Spectro test kits were used for the analysis of the physical properties of the n-hexane extract of Leptadenia hastata and a mass spectrometer was used to determine the physical properties of the extract. The analysis was carried out at National Agency of Food and Drug Administration and control (NAFDAC), Maiduguri office.

\section{Determination of $\mathbf{p H}$}

The indicator, range and test name chart were selected the indicator which was corresponding to the anticipated $\mathrm{pH}$ range. A test tube was filled with sample water to the $10 \mathrm{ml}$ line with the sample. The tube was inserted into the chamber of the spectrometer and screened as blank. The tube was removed from the spectrometer and an equal $\mathrm{ml}$ of the $\mathrm{pH}$ indicator from the chosen range was added. This was then capped and mixed. The tube was inserted into the chamber and scanned.

\section{Determination of Salinity}

$10 \mathrm{ml}$ of the sample was put in a test tube and 3 drops of saline indicator was added to the sample. This was titrated with saline titration reagent B The result obtained was then recorded.

\section{Results and Discussions}

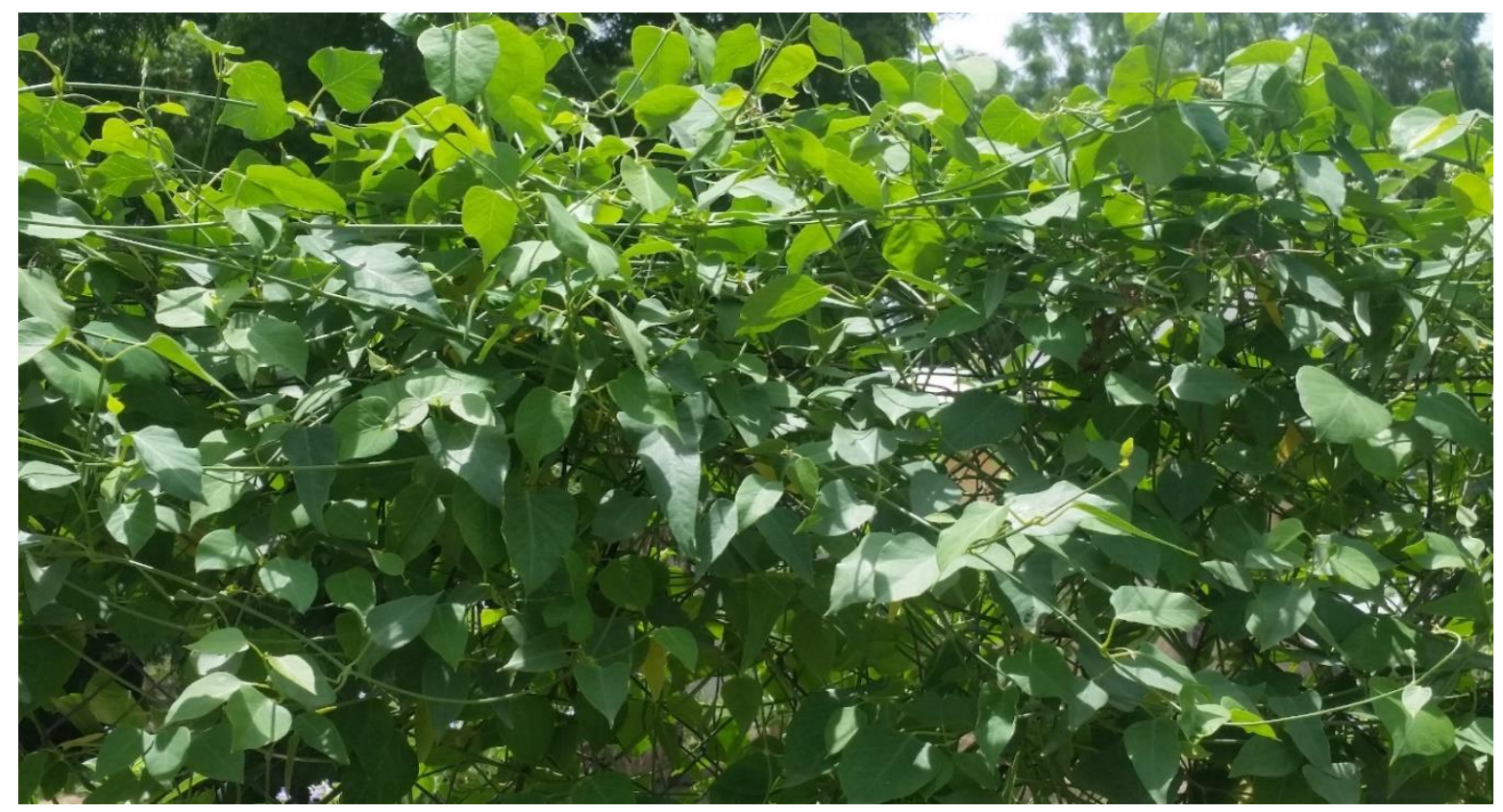

Figure 1: Leptadenia hastata (Pers.) Decne.

Table 1: The phytochemical constituents of n-hexane leaf extract of Leptadenia hastata

\begin{tabular}{|l|l|}
\hline Phytochemical & Result \\
\hline Cardiac Glycosides & + \\
\hline Steroids & + \\
\hline Terpenes & + \\
\hline Triterpenoids & + \\
\hline
\end{tabular}

+ Present 
Table 2: The Physical and Elemental Properties of n-hexane leaf extract of Leptadenia hastata

\begin{tabular}{|l|l|}
\hline Parameter/Element & Results $(\mathbf{m g} / \mathbf{l})$ \\
\hline Ammonia $\left(\mathrm{Nh}_{4}\right)$ & 0.12 \\
\hline Cadmium $(\mathrm{Cd})$ & Not Detected \\
\hline Calcium $(\mathrm{Ca})$ & 0.30 \\
\hline Chromium $(\mathrm{Cr})$ & 0.22 \\
\hline Cyanide $(\mathrm{Cn})$ & 0.08 \\
\hline Fluoride $(\mathrm{F})$ & 0.30 \\
\hline Iron $(\mathrm{Fe})$ & 0.04 \\
\hline Lead $(\mathrm{Pb})$ & Not Detected \\
\hline Magnesium $(\mathrm{Mg})$ & 0.10 \\
\hline Manganese $(\mathrm{Mn})$ & 0.08 \\
\hline Mercury $(\mathrm{Hg})$ & Not Detected \\
\hline Nickel $(\mathrm{Ni})$ & 2.03 \\
\hline Nitrates $\left(\mathrm{No}_{3}\right)$ & 0.18 \\
\hline pH & 9.8 \\
\hline Phosphate $\left(\mathrm{Po}_{4}\right)$ & 27.6 \\
\hline Potassium $(\mathrm{K})$ & 3.6 \\
\hline Salinity & 0.20 \\
\hline Silicon $(\mathrm{Si})$ & 0.04 \\
\hline Sodium $(\mathrm{Na})$ & 91.0 \\
\hline Sulphate $\left(\mathrm{So}_{4}\right)$ & 34.0 \\
\hline Zinc $(\mathrm{Zn})$ & 0.36 \\
\hline
\end{tabular}

The units of measurement is $\mathrm{mg} / \mathrm{l}$

\section{Discussions}

Natural products provide a significant source of potential drugs from which human kind has identified not only phyto-medicines and herbal remedies, but also some orthodox anti-diabetic drugs. Phytochemical analysis of n-hexane extract of Leptadenia hastata revealed the presence of steroids, cardiac glycosides, terpenes and triterpenoids (Table 1). The presence of these compounds were also reported by $[17,18]$. Terpenoids belong to an important class of natural products and several terpenoids have been reported as anti-diabetic agents [19-25]. These can act as hopeful agents in the treatment of diabetic retinopathy, neuropathy, nephropathy or in impaired wound healing by inhibiting several pathway involved in diabetes and its associated complications [26]. Although several authors [19, 20] have also reported flavonoids, sterols, tannins, saponins, alkaloids and polyphenols as bioactive anti-diabetic principles.

Metals are naturally occurring inorganic elements which are present in very small amounts in plants but are important for the vital processes of life. Diabetes has been associated with abnormalities in the metabolism of these trace metals [26-30]. Lead and cadmium are non-essential trace elements having functions neither in human body nor in plants. They induce various toxic effects in humans at low doses. The typical symptoms of lead poisoning are colic, anemia, headache, convulsions and chronic nephritis of the kidneys, brain damage and central nervous system disorders. Cadmium accumulates in human body and damages mainly the kidneys and liver [31]. In the present study, no trace of lead, mercury nor cadmium were detected in the elemental analysis of the n-hexane extract of the plant affirming its non-toxic nature (Table 2). 
Zinc has been found to have an insulin-like effect as that it enhances glucose uptake by inhibiting glycogen synthesis [30]. It has been found that zinc maintains the structural integrity of insulin [27] and also influences glyceraldehyde-3-phosphate dehydrogenase which is an enzyme involved in glycolysis [28]. Diabetic patients typically excrete excessive amounts of zinc in their urine and therefore supplementation is required [29, 30]. Deficiency of zinc increases beta cell vulnerability to free radical attack which is prevalent in the diabetic condition. In view of the positive role of zinc on pancreatic beta cells and insulin, the use of Leptadenia hastata in the treatment of diabetes mellitus may be attributed to considerable amounts of zinc present $(0.36 \mathrm{mg} / \mathrm{kg})$. The extract could also supplement zinc deficiency in diabetic patients.

Iron is an essential element for wide varieties of metabolic processes including playing pathogenic roles in diabetes mellitus and its complications [32]. Some trace elements ( $\mathrm{Cr}$, and $\mathrm{Mn}$ ) play important roles in metabolism and insulin action. Manganese may act like insulin in increasing the transport of glucose molecules into the adipose tissue by enhancing an existing low level of insulin [5, 32, 33]. Magnesium is needed for the secretion and synthesis of insulin, it also enhances cellular uptake of insulin also and therefore keep up their insulin sensitivity [34-36]. These elements were found in trace amounts in the n-hexane extract of Leptadenia hastata when analysed. Chromium involves as a cofactor in insulin-regulating activities [35]. It facilitates insulin binding and subsequent uptake of glucose molecules into the body cell and therefore decreases fasting glucose levels, enhances glucose tolerance and decreases total cholesterol in type II diabetic patients [35]. It has been found that chromium administration decreases fasting and postprandial glucose concentration. It can also decrease fatigue, excessive thirst, and frequent urination [36]. The potentiating role of chromium on insulin's action has been attributed to an increase in insulin binding to body cells due to an increase in the number or concentration of insulin receptors [38]. Leptadenia hastata was also found to be a rich source of copper, calcium, and phosphorus as also investigated by [36].

The relatively high concentration of sulphates $(340 \mathrm{mg} / \mathrm{l})$ which may play an anti-diabetic role. A study by [36] revealed that vanadium sulphate $\left(\mathrm{VOSO}_{4}\right)$ administration stimulated beta cell proliferation and differentiation from extra-islet precursor cells which helped in regeneration of beta islet cells and increased insulin secretion.

\section{Conclusions and Recommendations}

Medicinal plants have trace elemental and phytochemicals in bioavailable forms. These elements play an important role in many physiologic functions and also play a role in the management of diabetes mellitus. In this investigation, n-hexane extract of Leptadenia hastata was subjected to elemental and phytochemical analysis to determine its constituents and the present analysis revealed that the plant has some important trace elements and phytochemicals that are essential in the treatment of diabetes mellitus.

\section{Acknowledgements}

The researchers wish to acknowledge Dr S.T. Balogun who devoted so much time, energy, untiring effort and whose guidance as well as helpful advice has helped throughout the course of the research. Much gratitude goes to all staff of Human Anatomy department, Dr. J.V. Zirahei, Dr. 
D.S. Amaza Mr. N.I. Dibal and Mrs. H.B. Ishaya for the tireless effort and support given to me during the course of the work. The researchers also acknowledge the helpful advice and support of as well as technical support given by the staff Histology and Gross Anatomy lab, Department of Human Anatomy, Biochemistry and Pharmacognosy lab, all of the University of Maiduguri for their support and assistance during this research work.

\section{References}

[1] Sigel, H. and Sigel,A., (Eds.) Metal ions in biological systems, Marcel Dekkar Inc. New York, Chap.3, pp.47-90 (1988).

[2] Yamashita, C.I., Saiki M. and Sertié, J.A.A. Elemental analysis of leaves and extracts of Casearia medicinal plants by instrumental neutron activation analysis, Journal of Radioanalytical and Nuclear Chemistry, 2001, Vol. 270, No.1 181-186

[3] Miller, L.P. and Flemion, F., Phytochemistry, Inorganic elements and special group of elements, Vol. III, Litton educational publishing Inc., New York., pp. 1-40 (1973).

[4] Sarma, B., and Goswami, B.C., Qualitative elemental analysis of some selected antidiabetic medicinal plants of Assam using X-ray Fluorescence (XRF) technique, Asian Journal of Plant Science and Research, 2016, 6(3):71-79

[5] Siddiqui K., Bawazeer N., Joy S.S., Variation in macro and trace elements in progression of type 2 diabetes, Scientific World Journal, 2014461591.

[6] Nourmohammadi I., Shalmani I.K., Shaabani M., Ladan G., Hossein N., Zinc, copper, chromium, manganese and magnesium levels in serum and hair of insulin-dependent diabetics, Archives of Iranian Medicine, 2000, 3(3), 88-100

[7] Walter R.M. Jr, Uriu-Hare, J.Y., Olin, K.L, Oster, M.H., Anawalt, B.D., Critchfield, J.W., Keen, C.L., Diabetes Care, 1991,14,1050.

[8] El-Yazigi A, Hannan N, Raines DA, Diabetes Res, 1991, 18, 129.

[9] Bello, A., Aliero, A.A., Saidu Y. and Muhammad Phytochemical Screening, Polyphenolic Content and Alpha-Glucosidase Inhibitory Potential of Leptadenia hastata (Pers.) Decne. Nigeria. Bayero Journal of Pure and Applied Sciences. 2001, 19(2): 181-186.

[10] Aliero, A. and Wara, S.H.. Validating the Medicinal Potential of Leptadenia hastata, African Journal of Pharmacy and Pharmacology.2009, 3(6):335-338.

[11] Sanda, K.A., Sandabe, U.K., Auwal, M.S., Bulama, I., Bashir, T.M. Sanda, F. A., and Mairiga A.. Hypoglycemic and Antidiabetic Profile of the Aqueous Root Extracts of Leptadenia hastata in Albino Rats. Pakistan Journal of Biological Science. 2013, 16(4):190-4.

[12] Umaru, I.J., Ahmed, F.B., Umaru, H.A., and Umaru, K.I. Leptadenia hastata (Pers) Decne: Phytochemical, Pharmacological, Biotechnological, Botanical, Traditional Use and Agronomical Aspects, European Journal of Pharmaceutical and Medical Research 2018, 5(6):109-119.

[13] Umaru, I.J., Badruddin, F.A. and Umaru, H.A. Phytochemical, antifungal and antibacterial potential of Leptadenia hastata stem-bark extract. MOJ Toxicol. 2018, 4(4):263-268.

[14] Azwanida N.N., A Review on the Extraction Methods Used in Medicinal Plant: Principles, Strengths and Limitations, Medicinal and Aromatic Plants, 2015, 4(196):1-6.

[15] Williamson, E.M., Okpoko, D.T., Evans, F.J., (1996). Pharmacological Methods in Phytotherapy Research. John Wiley and Sons, Inc. Third Avenue, New York, USA. Pp. 155-167.

[16] Sofowora A. (1993). Medicinal Plants and Traditional Medicine in Africa. Spectrum books Ltd. Ibadan, Nigeria. PP 191-289.

[17] Mailafiya M.M. (2014) Phytochemical Studies and Effect of Methanol Leaf Extract of Leptadenia hastata (Pers.) Decne (Asclepiadaceae) on Acetic Acid Induced Writhes in Mice and Venom of Echis Ocellatus, being a Thesis Submitted to the School of Postgraduate Studies Ahmadu Bello University, Zaria. 
[18] Chukwudi E. I. and Yusha'u M., Phytochemical Screening and Brine Shrimp Lethality Assay of the Leaf Extracts of Cucurbita Maxima, Euphorbia Hirta, Leptadenia hastata and Mitracarpus Scaber, International Journal of Current Research in Life Sciences, 2016, 5(5):579-583.

[19] Tan MJ and Ye Y, Anti-Diabetic Activities of Triterpenoids Isolated from Bitter Melon Associated with Activation of the AMPK Pathway, Science Direct, 2008, 15(3):263-273

[20] Castellano, J.M., Guida, A., Delgado, T., Rada, M. and Cayeuela, J.A., Biochemical Basis of the Antibiotic Activity of Oleanolic Acid and Related Pentacyclic Triterpenes, Diabetes. 2013, 62(6):1791-1799.

[21] Burdi, D.K., Qureshi, S. and Ghangaro, A.B.,. An Overview of Available Hypoglycemic Triterpenoids and Saponins to Cure Diabetes Mellitus, Advancements in Life Sciences 2014, 1(3):119-128.

[22] Akinmoladun, A.C., Olaleye, M.T. and Farombi, E.O.,. Cardiotoxicity and Cardioprotective Effect of African Medicinal Plants, Toxicological Survey of African Medicinal Plants, 2014:395-421

[23] Wu Y. and Chen, S., Extraccted Triterpenes from Antrodia cinnamomea reduce the Inflammation to Promote Wound Healing via STZ Induced Hyperglycemia in Diabetic Mice Model, Frontiers in Pharmacology, 2016, 7:154

[24] Putta, S., Yarla, N.S., Surekha C., Aliev, G., Divakara, M. B., Santosh, M.S., Ramu, R. Zameer, F., Chintala, R., Rao, P.V., Shiralgi, Y. and Dhananjaya, B.L., Therapeutic Potentials of Triterpenes in Diabetes and its Associated Complications, Current Topics in Medicinal Chemistry, 2016, 16(23): 2532-42.

[25] Mukesh SS and Patil MB., Antidiabetic activity of Pongamia pinnata Leaf Extracts in AlloxanInduced Diabetic Rats. International Journal of Ayurveda Resources, 2010 1(4):199-204.

[26] Sani, U.M.,, Phytochemical Screening and Antidiabetic Effect of Extracts of the Seeds of Citrullus lanatus in Alloxan-induced Diabetic Albino Mice Journal of Applied Pharmaceutical Science, 2015, 5 (3):051-054

[27] Khan, A. R. and Awan, F. R., Metals in the pathogenesis of type 2 diabetes, Journal of Diabetes \& Metabolic Disorders, 2014, 13:16, 1-6.

[28] Tapiero H., Tew K.D., Trace elements in human physiology and pathology: zinc and metallothioneins, Biomed Pharmacother, 2003, 57, 399-411.

[29] Khan, K. Y., Khan, M. A., Niamat, R., Shah, G. M., Fazal, H., Seema, N., Hussain, I., Ahmad, I., Inayat, H., Jan, G. and Kanwal, F. ) Elemental Content of Some Anti-Diabetic Ethnomedicinal Species of Genus Ficus Linn. Using Atomic Absorption Spectrophotometry Technique, Journal of Medicinal Plants Research. 2012, 6(11):2136-2140

[30] Schlienger, J. L., Grunenberger, F. and Maier, E.A.. Disorders of Plasma Trace Elements in Blood Glucose Equilibrium. Press eMedicine 1998, 17:1076-1079.

[31] Swimnathan, S., Fonseca, V.A., Alam, M.G. and Shah, S.V.. The role of Iron in the Diabetes and Its Complications. 2007, Diabetes Care 30(12):1923-33.

[32] Djama, A.A.D. Djama, Kouassi-Goffri, M.C., Ofosu, F.G. and Aboh, J.K., Heavy Metal Analysis of Some Anti-Diabetic Medicinal Plants in Côte d'Ivoire, Current Research Journal of Biological Sciences. 2012, 4(5): 633-637.

[33] Rajendra A., Narayan V., Granavel I., Study on the analysis of Trace elements in Aloe Vera and its biological importance, Journal of applied sciences Research, 2007, 3(11), 1476-1478.

[34] Oyedeji, S. O., Adesina, A.A., Oke, T.O. and Tijani, Y.O., Evaluation of Essential Trace Metals in Female Diabetes Mellitus Patients in Nigerian Population, African Journal of Biotechnology, 2014, 13(18):1910-1914.

[35] Mooradian A.D., Morley J.E, Micronutrient status in diabetes mellitus, American Journal of Clinical Nutrition, 1987, 45(5), 877-895.

[36] Umaru, I.J., Badruddin, F.A. and Umaru, H.A., Phytochemical, antifungal and antibacterial potential of Leptadenia hastata stem-bark extract. MOJ Toxicol. 2018, 4(4):263-268. 
[37] Missaoui, S., Rhouma, K.B., Yacoubi, M.T., Sakly, M. and Terourbi, O., Vanadyl Sulfate Treatment Stimulates Proliferation and Regeneration of Beta Cells in Pancreatic Islets, Journal of Diabetes Research 2014:1-7.

[38] Piero M.N., Njagi J.M., Kibiti C.M., Ngeranwa J.J.N., Njagi E.N.M. and Miriti P.M., The role of vitamins and mineral elements in management of type 2 diabetes mellitus: A review, South Asian Journal of Biology Sciences, 2012, 2, 107- 115.

*Corresponding author.

E-mail address: marthaorendua@ gmail.com 